\title{
Glandular trichomes on the leaves and flowers of Bellardia trixago and Parentucellia viscosa (Orobanchaceae)
}

\author{
Lacerda, R.* and Ascensão, L.* \\ * Universidade de Lisboa, Faculdade de Ciências, Departamento de Biologia Vegetal, IBB, Centro de \\ Biotecnologia Vegetal, Campo Grande, 1749-016 Lisboa, PORTUGAL \\ e-mail: lia.ascensão@fc.ul.pt
}

Bellardia trixago and Parentucellia viscosa are two annual hemiparasitic species belonging to Orobanchaceae family (ex. Scrophulariaceae) [1].They are native to Europe but have been introduced as alien species in other continents. Due to their parasitic nature and high fecundity these two species have a significant impact on legumes and cereal growth rates [2]. Phytochemical studies in several Orobanchaceae species have shown the presence of iridoid glucosides and flavonoids [3, 4], compounds with a wide range of biological activities [5]. Detailed studies in Orobanchaceae secretory structures are rare, although numerous bioactive compounds were produced by their specialized glandular cells. Thus, the present work aimed to study the morphology, ontogeny and histochemistry of B. trixago and $P$. viscosa glandular trichomes.

Leaves and flowers at different stages of development were collected from natural populations of Bellardia trixago (L.) All. and Parentucellia viscosa (L.) Caruel occurring in Portugal. Samples fixed with glutaraldehyde were prepared for scanning electron microscopy (SEM) or embedded in Leica Historesin ${ }^{\circledR}$ for anatomy, following standard methods. Histochemical tests and control procedures were carried out in fresh material to localize the main chemical classes of compounds present in the secretion.

The aerial organs of both species are coated by sticky glands that exude a viscose secretion in which small insects are often trapped. Two morphological distinct types of capitate glandular trichomes are presented. Long-stalked capitate trichomes, which produce a mucilaginous secretion, exhibit a highly unusual morphology, perhaps unique, that as far as we know, was not previously described. They have a multicellular uniseriate stalk and a complex ellipsoidal glandular head. The core of the head, formed by a single cell, is surrounded by a domed or bell-shaped layer of glandular cells. The central cell of the head, with a remarkable length, has a high polarity; the protoplasm at the apex contains several small vacuoles, while a predominant nucleus surrounded by numerous chloroplasts occurs at basal region. This specialized cell may be "the trichome power house" supplying energy and carbon to the cells of the external layer for mucilage biosynthesis. Despite the similar morphology of these trichomes in the two species, those of B. trixago have longer stalks and larger glandular heads. They occur on leaves, bracts and sepals, especially at the margins and along the main veins of abaxial surfaces. The other type of capitate trichomes has a short unicellular stalk and an ovoid to globoid head with four cells. They are rare on B. trixago but very frequent on $P$. viscosa along the veins of both organ surfaces. The mucilage of long-stalked capitate trichomes may play an important adaptive role in the xeric Mediterranean environments and may also act as chemical defense against herbivores and pathogens. Short-stalked trichomes are probably hydathodes excreting actively water, function that was recently recognized to the similar trichomes of Odontites vernus [6]. Further studies are needed to confirm the role of these glandular trichomes in hemparasitic species.

The authors acknowledge the funding by Fundação para a Ciência e Tecnologia through the project FCT PEstOE/EQB/LA0023/2011. 


\section{References}

[1] Tank D. et al., Aust. Syst. Bot. 19, 289-307, 2006.

[2] Rank C. et al., J. Weed Res. 44, 265-270, 2004.

[3] Vendelli A. et al., Nat. Prod. Res. 27, 1413-1416, 2013.

[4] Tomás-Barberán F. et al., J. Phytochemistry 27, 2631-2645, 1988.

[5] Dinda B. et al., Chem. Pharm. Bull. 55, 159-222, 2007.

[6] Tesitel J. and Tesarova M., Plant Biol. 15, 119-125, 2013.
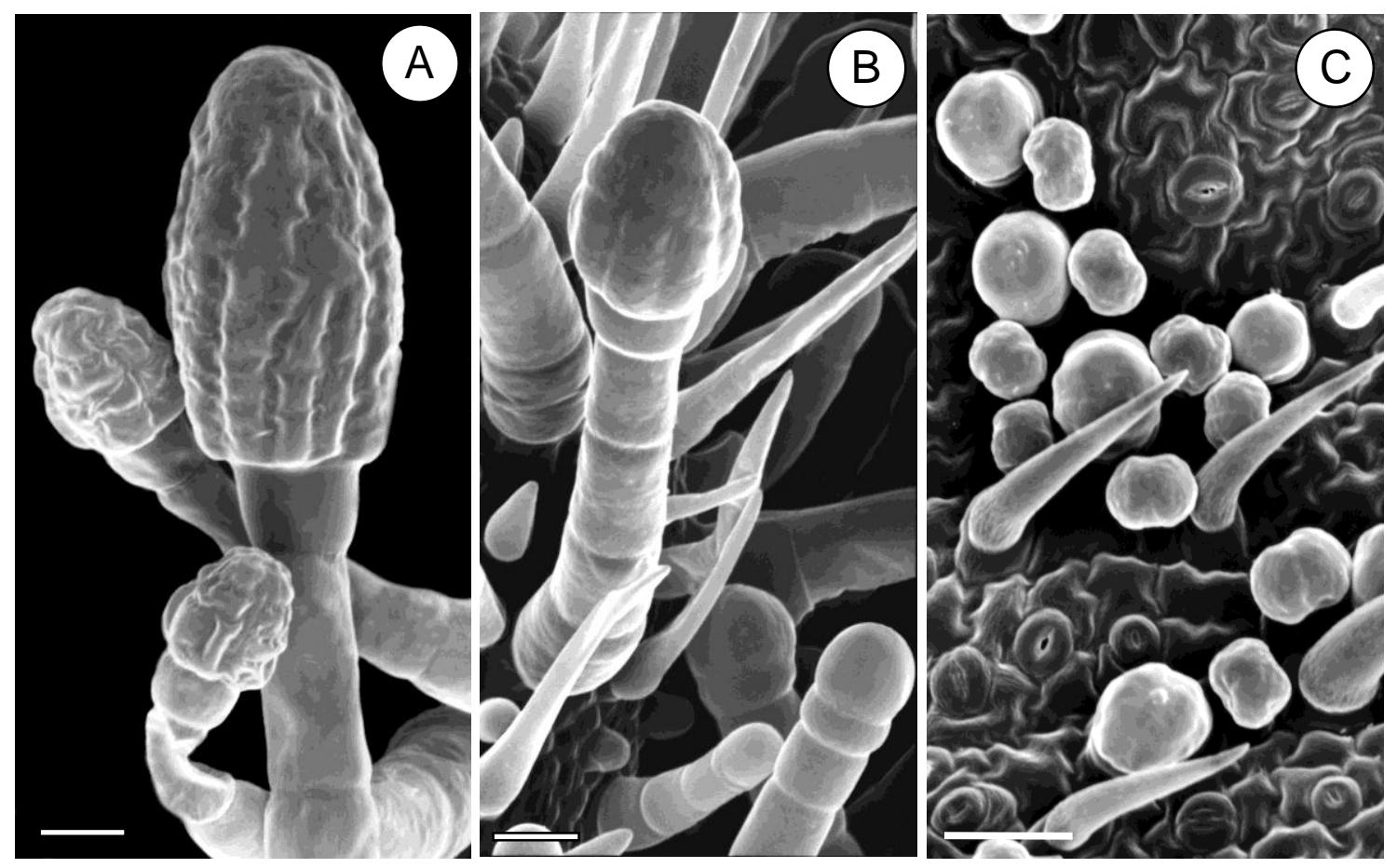

Figure 1. SEM micrographs of Bellardia.trixago (A) and Parentucellia viscosa (B, C) glandular trichomes. A, B Long-stalked capitate trichomes. C Short-stalked capitate trichomes on the veins of the abaxial surface of a leaf. Bars $=25 \mu \mathrm{m}(\mathrm{A}, \mathrm{B}) ; 50 \mu \mathrm{m}(\mathrm{C})$. 